\title{
DETERMINANTS OF STUDYING AT “HOME” WHILE LIVING “ABROAD”: A GROUNDED THEORY STUDY ON COLLEGE-CHOICE AMONG WESTERN EXPATRIATE AND TRANSNATIONAL DISTANCE STUDENTS IN THE REPUBLIC OF KOREA
}

\author{
William H. Stewart ${ }^{1}$ \\ Hankuk University of Foreign Studies, Republic of Korea
}

\begin{abstract}
Since the mid 1980s to today, the Republic of Korea has experienced significant immigration. The influx of various forms of migrants has started changing the makeup of an otherwise ethnically homogenous society. Despite such demographics changes, commensurate adjustments to government policies or institutional services have not necessarily occurred. Globalization and related technological advancements, however, have made it possible to sidestep limitations/obstacles resulting from a lack of recognition or change. In the case of education, the Internet has enabled, at least for some, the ability to continue pursuing education "home", while continuing to work and live "abroad". Nevertheless, the determinants of distance education in such instances have not been adequately investigated.

Though college choice literature is plentiful, it is largely traditional student oriented and based on face-to-face instruction. Few studies have investigated distance education college choice, which is largely composed of non-traditional student groups. As a result, the motivations and influences on this population's college enrollment are poorly understood. This grounded theory study investigated the college choice process of long-term foreign residents in Korea who were enrolled in distance education programs in their home countries or abroad elsewhere. Eight expatriate and two transnational distance students participated in interviews where themes of repatriation as a determinant for the impetus to study surfaced, with local educational ecosystem inaccessibility, and home country ecosystem convenience as mediating factors. Implications for policy and directions for local Korean educational institutions are discussed as well as for institutions "abroad". Future areas of research are suggested.
\end{abstract}

Keywords: distance students, transnational education, international education, college choice, Korea, globalization, grounded theory

\footnotetext{
${ }^{1}$ Correspondence: 107 Imun-ro, Dongdaemun-gu, Seoul 02450, South Korea; wstewart@hufs.ac.kr
} 


\section{Introduction}

Since the 1980s, the demographic makeup of immigrants in the Republic of Korea (hereafter Korea) has largely consisted of unskilled migrant workers from China (Shin \& Moon, 2019). While this characterization is generally true today (see MoJ, 2016), it glosses over a more complex portrait of migration and immigration that has emerged in the early 21 st century. For example, immigration policies based on this majority immigrant population overlook skilled-labor or professional migrant workers (e.g., IT workers, researchers, university faculty, etc.), or marriage-migrants from developed countries who simply do not fit into the conventional image of who migrants are considered to be (unskilled) or what they have traditionally looked like (Asian) in Korea (Shin \& Moon, 2019). In simpler terms, there is a growing diversity among the foreign-born population that has not been adequately recognized (Shin \& Moon, 2019). When it comes to education, these changes in immigration demographics overlap with international, transnational, and distance education (Stewart, 2020).

This paper builds on prior work (Stewart, 2017, 2020) which investigated the phenomenon of long-term foreign residents who, while living in Korea, chose to pursue higher education at "home" online. Stewart's (2020) multicase study of western distance students found that the average length of time they were living in Korea was in excess of 10 years, many of whom were married to local citizens, had children, had bought property, and committed to their careers and lives on the peninsula. Despite the establishment of Korea as their "homes", education uniquely stood apart. Although these students had a privileged socioeconomic vantage point by virtue of their western origins, status as native English speakers, and having an undergraduate education prior to migrating to Korea for work (Stewart, 2020), they still shared many of the same economic motivations that virtually all migrants do such as unemployment and/or underemployment (Collins, 2014), and marginalized/shrunken labor markets in their home countries (Lan, 2011). For example, these individuals were funneled into the same Anglophone-centric industry (teaching English as a Foreign Language $[\mathrm{EFL}]$ ) by virtue of their native language, and the lack of other viable work opportunities despite being categorized as skilled-labor migrants. In order to pursue additional career paths or simply move up the career ladder in their current occupations, these students turned to education at "home" at a distance.

While analogous education programs did in fact exist locally (and taught in English as an international language) (Stewart, 2017, 2020), such options were ignored, underscoring the role that the internet has had in reducing barriers to goods and services in an increasingly globalized world. Despite these "cases" of distance students (in Korea and elsewhere) surfacing in the literature, they have not been adequately recognized or investigated (Andrews \& Tynan, 2010; Harrison et al., 2018). Further, it is not clear what the motivations, influences, or determinants of the decision to study in one's country of citizenship are while living a life abroad. Simply stated, how the college choice process occurs among expatriate distance students is not known (throughout this paper, the terms college and university are used interchangeably).

Conventionally, college choice is a complex decision-making process comprising many internal/external factors. Examples of such include push-pull factors, in addition to the individual student's habitus. For instance, in the case of Korea, the habitus of a Korean returnee student would likely include their familiarity with life abroad outside of Korea, and factors that pull or attract them to distance education programs abroad could be congruence with an educational paradigm, while being pushed away from local ones that are linguistically inaccessible (Greenholtz \& Kim, 2009). For the expatriate distance students in Stewart's 
(2020) study, linguistically accessibility or program availability was not necessarily an issue; rather other factors were at play.

Prior research has shown similar nuance among students who attend local transnational branch campuses versus a home university campus abroad (Wilkins et al., 2012), as well as differences among college-going motivations of expatriates attending transnational branch campuses (Rensimer, 2016). While typological differences (e.g., traditional vs non-traditional) among students may not be revolutionary in nature, such student voices have been glossed over (Andrews \& Tynan, 2010; Harrison et al., 2018). There may be additional or overlooked nuance that has otherwise gone unnoticed (Gemmell \& Harrison, 2017; Rensimer, 2016). Thus, the purpose of this paper is threefold: to investigate the varying contexts of migrants in Korea as called for in prior research (i.e., Shin \& Moon, 2019), to investigate college-choice among an understudied population, and among a specific subtype of student (Rensimer, 2016). As such, this study was guided by the following research questions:

1. What are the demographic and program characteristics of expatriate and transnational distance students in Korea?

2. Why do students not study at national or transnational institutions/programs in their host country

3. What factors influence/motivate students' decisions to seek distance education opportunities outside of their host country?

4. How do students identify and choose their respective institutions outside of their host country?

\section{Literature Review}

\section{The Evolution of International Education Options}

The internationalization of face-to-face higher education as a whole has steadily become a complex and nuanced migration industry (Beech, 2018; Choi et al., 2019) with educational migrants appearing at all levels of education from primary, secondary, and tertiary education. The push-pull model of international student destination choice highlights how various environmental pressures in one's home country may "push" one to seek education abroad such as the lack of a particular program (Vrontis et al., 2007), or factors that "pull" students towards institutions by prestige or reputation, or even perceived benefit of the degree (Cha \& Chang, 2009; Lam et al., 2011; Rensimer, 2016). For decades, international education has been characterized by student mobility and the need to physically move from one place to another in order to attend an educational program, and these students are uniformly referred to as international students. Since the 1990's, however, potential international students saw the beginnings of "international" education at home through the establishment of local branch campuses of a foreign university (McMahon, 1992).

These campuses, often referred to as offshore or transnational branches, offer an official, physical presence of a foreign university in another country (Wilkins et al., 2012). This additional form of educational delivery enabled students to obtain an "international" education without the need for traditional physical mobility from home- to host-country. With students then being able to choose between the home university and the branch campus, researchers then began investigating the motivations for differences between campus destinations (see Fang \& Wang, 2014; Wilkins et al., 2012). Prior to the internet, robust ICT infrastructure, and easily accessible distance programs, physical branch campuses have been some of the only options available for "international" higher education if unwilling to 
undertake the disruption of physical mobility. These campuses have even served as educational lifelines for "returnees" or "third-culture kids" who may lack the linguistic ability or sociocultural knowledge to attend national college programs successfully after repatriation (Greenholtz \& Kim, 2019; Kim, 2018; Pollock \& Van Reken, 2009).

These reasons for attending transnational campuses, however, are not limited to students wanting to enter colleges or universities after high school (Rensimer, 2016); they also apply to adult, immigrant, non-traditional students wishing to do the same (Stewart, 2020). Since the widespread adoption of the Internet and development of distance programs, local transnational campuses, are not the only way to access higher education from a provider based elsewhere in the world (Stewart, 2019). Nevertheless, one consequence of this potential access is formation of new contextual student scenarios that have often not been (formally at least) recognized by institutions of higher learning (Harrison et al., 2018).

The importance of recognizing these differences relates to adequate support - for example, TCK's who return to their countries of citizenship for college often have higher attrition rates (Pollock \& Van Reken, 2009). Common student classifications (i.e., regular, international) end up homogenizing distinctly different cases (e.g., expatriate, transnational) of students (Rensimer, 2016). Further, even when referring to international or transnational distance students in the literature, differences in the meanings of the two terms are unclear (Kosmützky \& Putty, 2016). For example, the term 'international' is often a catch-all label used to describe students who do not share the same nationality where the institution is based, and which also typically involves physical mobility from one's home-country to a hostcountry.

However, this conventional understanding does not adequately account for differences in the original purpose of migration such as labor versus education (Madge et al., 2015; Stewart, 2017, 2019), or the nuances (e.g., skilled labor migrants) within the migrant population as a whole (Shin \& Moon, 2019). Rensimer (2016) called for "nuanced approaches to research on expatriate and international students and recognition of their differing constraints, needs, resources, and aspirations" (p. 93). In that vein, college choice studies highlight some of these same challenges since they are predominantly traditional-student oriented (Iloh, 2018).

\section{College Choice Overview}

College choice models can generally be described as outlining three broad phases from exploration of available institutions, listing a set of colleges to choose from/exclude for various reasons, and ultimately enrollment (Lansing, 2017). Models can be economic in nature which present the internal decision-making process as one based on the perceived economic value an institution can provide through its degrees. Models can also be focused on status-attainment which take into consideration a host of determinant variables (e.g., prior GPA, parents' highest level of educational attainment, socioeconomic status, etc.) (Vrontis et al., 2007).

The models, pragmatically, are not mutually exclusive and combining both economic and status-attainment perspectives can more holistically analyze push-pull factors and present a more detailed picture of individual (e.g., socioeconomic status, culture, religion, gender, parental educational attainment, personal values, aspirations, academic ability) and environmental (e.g., economic ability, financial aid, social influence, marketing/recruiting influence) determinants, and characteristics of the institutions (e.g., cost, location, program availability, reputation, prestige) (Vrontis et al., 2007). Moreover, the combination of economic and status-attainment perspectives may be far more powerful explanatorily than 
any one perspective alone. In transnational settings, however, other applicable factors such as geographic distance from one's home country, cultural distance, linguistic ability, religious compatibility, and even travel attractions play a part in the choice process (Lam et al., 2011; Wilkins et al., 2012).

Nevertheless, among the literature, a high degree of homogeneity in sampling is common. This is notably the focus on a) traditional secondary school students (i.e., 16-24 years old), b) undergraduate college choice as first-time freshman, c) the face-to-face mode of delivery, and d) a national frame of reference (Lansing, 2017). An overview of this homogeneity in scholarship is provided in Table 1 in chronological order. While certain characteristics of this process will no doubt be similar or shared (e.g., information gathering stages) among both traditional and non-traditional students (see Vrontis et al., 2007), there is an absence of adult immigrant sampling, which would contribute to the picture of college choice in a more modern context. Iloh (2018) has described this youth-centric focus limiting as it leaves out large swathes of the college-going population. The aforementioned homogeneity aside, there is some research investigating more unique socioeconomic factors that can affect/influence how students choose college such as transportation mode (e.g., Ewing et al., 2004), underrepresented populations of college-seeking students (in the United States) by ethnic or racial minority status (e.g., Teranishi et al., 2004), first-generation children immigrants (e.g., Griffin et al., 2012), or even undocumented students (e.g., Pérez, 2010).

Despite this robust literature base with students and their choice of traditional brick and mortar programs, there are only few studies (e.g., Harris \& Martin, 2012; Jaggars, 2014; Lansing, 2017; Roblyer, 1999) that examine the college choice motivations of distance students who enroll in distance programs outright (or even the more recent phenomenon of students attending K-12 virtual schools [see Barbour, 2017; Rice, 2006]). On the one hand, the absence of research on distance program choice is logical prior to the widespread adoption of the Internet and proliferation of online distance programs (though there are massive scale distance education programs delivered as telecourses today, most notably in India- see Panda, 2005). On the other, the poverty of recognition of distance program choice is a glaring omission today given its ubiquity (Lansing, 2017).

\section{Transnational Branch Campus Choice Scholarship}

In transnational education, much change has been seen over the last 20 years (Wilkins, 2016). Since the 1990s, various universities began pursuing revenue growth strategies by exporting their brand and educational offerings in the form of transnational programs and the establishment of branch campuses in various host countries around the world. Thus, college choice studies situated at offshore branch campuses begin largely from 2000 onwards (Wilkins \& Huisman, 2012). Table 2 was adapted from Wilkins et al. (2012) and includes additional scholarship on international and/or transnational college choice up to 2019. Similar to Table 1, Table 2 calls attention to the target student population, level of study, delivery medium. 
Table 1

Overview of National College Choice Scholarship

\begin{tabular}{|c|c|c|c|c|}
\hline Source & $\begin{array}{l}\text { Student } \\
\text { Type }\end{array}$ & $\begin{array}{c}\text { Study } \\
\text { Level }\end{array}$ & $\begin{array}{l}\text { Delivery } \\
\text { Medium }\end{array}$ & $\begin{array}{l}\text { National } \\
\text { Context }\end{array}$ \\
\hline Sewell \& Shah, 1968 & Highschool & Undergraduate & $\mathrm{F} 2 \mathrm{~F}$ & American \\
\hline Punj \& Staelin, 1978 & Adult & Graduate & $\mathrm{F} 2 \mathrm{~F}$ & American \\
\hline Chapman, 1981 & Highschool & Undergraduate & $\mathrm{F} 2 \mathrm{~F}$ & American \\
\hline Jackson, 1982 & Highschool & Undergraduate & $\mathrm{F} 2 \mathrm{~F}$ & American \\
\hline Fuller et al., 1982 & Highschool & Undergraduate & $\mathrm{F} 2 \mathrm{~F}$ & American \\
\hline Hanson \& Litten, 1982 & Highschool & Undergraduate & $\mathrm{F} 2 \mathrm{~F}$ & American \\
\hline Hossler \& Gallagher, 1987 & Highschool & Undergraduate & $\mathrm{F} 2 \mathrm{~F}$ & American \\
\hline Manski \& Wise, 1983 & Highschool & Undergraduate & $\mathrm{F} 2 \mathrm{~F}$ & American \\
\hline Chapman, 1984 & Highschool & Undergraduate & $\mathrm{F} 2 \mathrm{~F}$ & American \\
\hline Schwartz, 1985 & Highschool & Undergraduate & $\mathrm{F} 2 \mathrm{~F}$ & American \\
\hline Bers \& Smith, 1987 & Adult & Undergraduate & $\mathrm{F} 2 \mathrm{~F}$ & American \\
\hline Hossler et al., 1999 & Highschool & Undergraduate & $\mathrm{F} 2 \mathrm{~F}$ & American \\
\hline Roblyer, 1999 & Highschool & Undergraduate & $\mathrm{D}$ & American \\
\hline Ewing et al., 2004 & Highschool & Undergraduate & $\mathrm{F} 2 \mathrm{~F}$ & American \\
\hline Teranishi et al., 2004 & Highschool & Undergraduate & $\mathrm{F} 2 \mathrm{~F}$ & American \\
\hline Rice, 2006 & Primary, Secondary & $\mathrm{K}-12$ & $\mathrm{D}$ & American \\
\hline Vrontis et al., 2007 & Highschool & Undergraduate & $\mathrm{F} 2 \mathrm{~F}$ & Western \\
\hline Perez, 2010 & Highschool & Undergraduate & $\mathrm{F} 2 \mathrm{~F}$ & American \\
\hline Griffin et al., 2012 & Highschool & Undergraduate & $\mathrm{F} 2 \mathrm{~F}$ & American \\
\hline Harris \& Martin, 2012 & Adult & Mostly Undergraduate & $\mathrm{D}$ & American \\
\hline Wilkins et al., 2013 & Highschool & Undergraduate & $\mathrm{F} 2 \mathrm{~F}$ & UK \\
\hline Jaggars, 2014 & Adult & Community College & $\mathrm{D}$ & American \\
\hline El Nemar \& Vrontis, 2016 & Highschool & Undergraduate & $\mathrm{F} 2 \mathrm{~F}$ & Lebanon \\
\hline Barbour, 2017 & Primary, Secondary & $\mathrm{K}-12$ & $\mathrm{D}$ & American \\
\hline Lansing, 2017 & Adult & Undergraduate & $\mathrm{D}$ & American \\
\hline
\end{tabular}

Note: $\mathrm{F} 2 \mathrm{~F}=$ Face-to-Face, $\mathrm{D}=$ Distance 
These studies also present a recurring focus on high school/undergraduate students and face-to-face delivery, as well as ambiguity when investigating students under the broad label of "international" (see Rensimer, 2016). Only Wilkins et al. (2012) and Rensimer (2016) have specifically discussed the possibility of expatriate students on campus among these studies; few studies explicitly disambiguate between local citizen students, expatriate/immigrant students (long term foreign residents), and international students (temporary education migrants). The overly broad use of "international" as a research analytic (Rensimer, 2016) continues to be problematic since it glosses over different contextual factors. Moreover, this practice of overly broad student categorization has not been limited to face-to-face programs; it is equally problematic or unclear in distance education literature (Harrison et al., 2018; Kosmützky \& Putty, 2016). This can make it difficult to parse differences between similar but different categories of students (Stewart, 2019).

\section{Table 2}

International/Transnational College Choice Scholarship

\begin{tabular}{|c|c|c|c|c|c|}
\hline Source & Student Type & $\begin{array}{l}\text { Study } \\
\text { Level }\end{array}$ & $\begin{array}{l}\text { Delivery } \\
\text { Medium }\end{array}$ & Host Country & $\begin{array}{l}\text { University Home } \\
\text { Country/Region }\end{array}$ \\
\hline $\begin{array}{l}\text { McMahon, } \\
1992\end{array}$ & Unspecified & Unspecified & $\mathrm{F} 2 \mathrm{~F}$ & United States & Various \\
\hline $\begin{array}{l}\text { Joseph \& } \\
\text { Joseph, } 2000\end{array}$ & Highschool & Undergraduate & $\mathrm{F} 2 \mathrm{~F}$ & New Zealand & Indonesia \\
\hline $\begin{array}{l}\text { Mazzarol \& } \\
\text { Soutar, } 2002\end{array}$ & $\begin{array}{l}\text { Highschool, } \\
\text { Adult }\end{array}$ & $\begin{array}{l}\text { Undergraduate, } \\
\text { Graduate }\end{array}$ & $\mathrm{F} 2 \mathrm{~F}$ & Australia & Asia \\
\hline $\begin{array}{l}\text { Binsardi \& } \\
\text { Ekwulugo, }\end{array}$ & $\begin{array}{l}\text { Highschool, } \\
\text { Adult }\end{array}$ & $\begin{array}{l}\text { Undergraduate, } \\
\text { Graduate }\end{array}$ & $\mathrm{F}_{2} \mathrm{~F}$ & United Kingdom & Developed, Developing \\
\hline Pimpa, 2005 & $\begin{array}{l}\text { Highschool, } \\
\text { Adult }\end{array}$ & $\begin{array}{l}\text { Undergraduate, } \\
\text { Graduate }\end{array}$ & $\mathrm{F} 2 \mathrm{~F}$ & Australia & Thailand \\
\hline $\begin{array}{l}\text { Shanka et al., } \\
2005\end{array}$ & $\begin{array}{l}\text { Highschool, } \\
\text { Adult }\end{array}$ & Unspecified & $\mathrm{F} 2 \mathrm{~F}$ & Australia & $\begin{array}{l}\text { Indonesia, Malaysia, } \\
\text { Singapore }\end{array}$ \\
\hline $\begin{array}{l}\text { Gatfield \& } \\
\text { Chen, } 2006\end{array}$ & $\begin{array}{l}\text { Highschool, } \\
\text { Adult }\end{array}$ & Unspecified & $\mathrm{F} 2 \mathrm{~F}$ & $\begin{array}{l}\text { Australia, United } \\
\text { Kingdom, United }\end{array}$ & Taiwan \\
\hline $\begin{array}{l}\text { Li \& Bray, } \\
2007\end{array}$ & $\begin{array}{l}\text { Highschool, } \\
\text { Adult }\end{array}$ & $\begin{array}{l}\text { Undergraduate, } \\
\text { Graduate }\end{array}$ & $\mathrm{F} 2 \mathrm{~F}$ & Hong Kong, Macau & China \\
\hline $\begin{array}{l}\text { Maringe \& } \\
\text { Carter, } 2007\end{array}$ & $\begin{array}{l}\text { Highschool, } \\
\text { Adult }\end{array}$ & $\begin{array}{l}\text { Undergraduate, } \\
\text { Graduate }\end{array}$ & $\mathrm{F} 2 \mathrm{~F}$ & United Kingdom & Africa \\
\hline Chen, 2007 & Adult & Graduate & $\mathrm{F} 2 \mathrm{~F}$ & Canada & $\begin{array}{l}\text { China, Hong Kong, } \\
\text { Japan, Korea, Taiwan }\end{array}$ \\
\hline Bodycott, 2009 & Highschool & Undergraduate & $\mathrm{F}_{2} \mathrm{~F}$ & Various & China \\
\hline
\end{tabular}


Table 2

International/Transnational College Choice Scholarship

\begin{tabular}{|c|c|c|c|c|c|}
\hline Source & Student Type & $\begin{array}{l}\text { Study } \\
\text { Level }\end{array}$ & $\begin{array}{l}\text { Delivery } \\
\text { Medium }\end{array}$ & Host Country & $\begin{array}{l}\text { University Home } \\
\text { Country/Region }\end{array}$ \\
\hline $\begin{array}{l}\text { Abubakar et } \\
\text { al., } 2010\end{array}$ & $\begin{array}{l}\text { Highschool, } \\
\text { Adult }\end{array}$ & $\begin{array}{l}\text { Undergraduate, } \\
\text { Graduate }\end{array}$ & $\mathrm{F} 2 \mathrm{~F}$ & Australia & Malaysia, Thailand \\
\hline $\begin{array}{l}\text { Padlee et al., } \\
2010\end{array}$ & $\begin{array}{l}\text { Highschool, } \\
\text { Adult }\end{array}$ & $\begin{array}{l}\text { Undergraduate, } \\
\text { Graduate }\end{array}$ & $\mathrm{F} 2 \mathrm{~F}$ & Malaysia & Southeast Asia \\
\hline $\begin{array}{l}\text { Lam et al., } \\
2011\end{array}$ & $\begin{array}{l}\text { Highschool, } \\
\text { Adult }\end{array}$ & $\begin{array}{l}\text { Undergraduate, } \\
\text { Graduate }\end{array}$ & $\mathrm{F} 2 \mathrm{~F}$ & Malaysia & $\begin{array}{l}\text { Indonesia, Iran, China, } \\
\text { Nigeria, Libya, Europe }\end{array}$ \\
\hline $\begin{array}{l}\text { Wilkins \& } \\
\text { Epps, } 2011\end{array}$ & $\begin{array}{l}\text { Highschool } \\
\text { Expatriates }\end{array}$ & Undergraduate & $\mathrm{F} 2 \mathrm{~F}$ & $\begin{array}{l}\text { United Kingdom UAE } \\
\text { Branch Campus }\end{array}$ & Middle East, Africa \\
\hline $\begin{array}{l}\text { Wilkins et al., } \\
2012\end{array}$ & $\begin{array}{l}\text { Highschool, } \\
\text { Adult }\end{array}$ & $\begin{array}{l}\text { Undergraduate, } \\
\text { Graduate }\end{array}$ & $\mathrm{F} 2 \mathrm{~F}$ & $\begin{array}{l}\text { Various Transnational } \\
\text { Branch Campuses in }\end{array}$ & $\begin{array}{l}\text { Emirates, India, } \\
\text { Pakistan, African }\end{array}$ \\
\hline $\begin{array}{l}\text { Fang \& Wang, } \\
2014\end{array}$ & Highschool & Undergraduate & $\mathrm{F} 2 \mathrm{~F}$ & Korea & China \\
\hline $\begin{array}{l}\text { Özoğlu, Gür, \& } \\
\text { Coşkun, } 2015\end{array}$ & Highschool & Undergraduate & $\mathrm{F} 2 \mathrm{~F}$ & Turkey & Central Asia \\
\hline $\begin{array}{l}\text { Rensimer, } \\
2016\end{array}$ & Expatriate & Undergraduate & $\mathrm{F} 2 \mathrm{~F}$ & United Arab Emirates & $\begin{array}{l}\text { Asia. Middle East, } \\
\text { North Africa }\end{array}$ \\
\hline $\begin{array}{l}\text { Kim et al., } \\
2018\end{array}$ & Highschool & Undergraduate & $\mathrm{F} 2 \mathrm{~F}$ & American & Asia \\
\hline Park, 2019 & Highschool & Undergraduate & $\mathrm{F} 2 \mathrm{~F}$ & Korea & China \\
\hline
\end{tabular}

Note: F2F = Face-to-Face

\section{Methodology}

Since student motivations were the primary concern in this investigation, a grounded theory approach was selected since its purpose is to suggest or approximate an explanation for why a given phenomenon exists (Creswell, 2013), and to "generate or discover a theory or abstract analytical schema of a phenomenon" that is "grounded in the experience and perceptions of the participants" (Creswell, 2015, p. 451). Epistemologically, this researcher presents the findings as "a construct produced by the interaction between the interpreter and the interpreted as situated in society. Knowledge of the observed is constructed rather than discovered" (Levers, 2013, p. 4).

\section{Sampling}

Since the literature is inconsistent in both terminology and definition (e.g., home student, domicile student, national student, expatriate, home student abroad, international, transnational, etc.) (Kosmützky \& Putty, 2016; Rensimer, 2017, Stewart, 2017), Stewart's 
(2017) conceptual model was used to delineate the target type of distance student as either expatriate or transnational as illustrated in Figure 1.

Eligible participants needed to be residing in Korea and be taking or have completed a distance program based outside of Korea. The intention was to recruit participants from various national/regional backgrounds and genders, currently studying (or graduated) while living in Korea. Theoretical variation was considered to be an emergent characteristic of the study with recruiting material disseminated in 20 languages through various channels. However, this researcher was unsuccessful in achieving a wide degree of variation by national/regional background, ultimately only successfully recruiting western immigrants studying at western institutions online.

Figure 1.

Stewart's Model of Distance Students

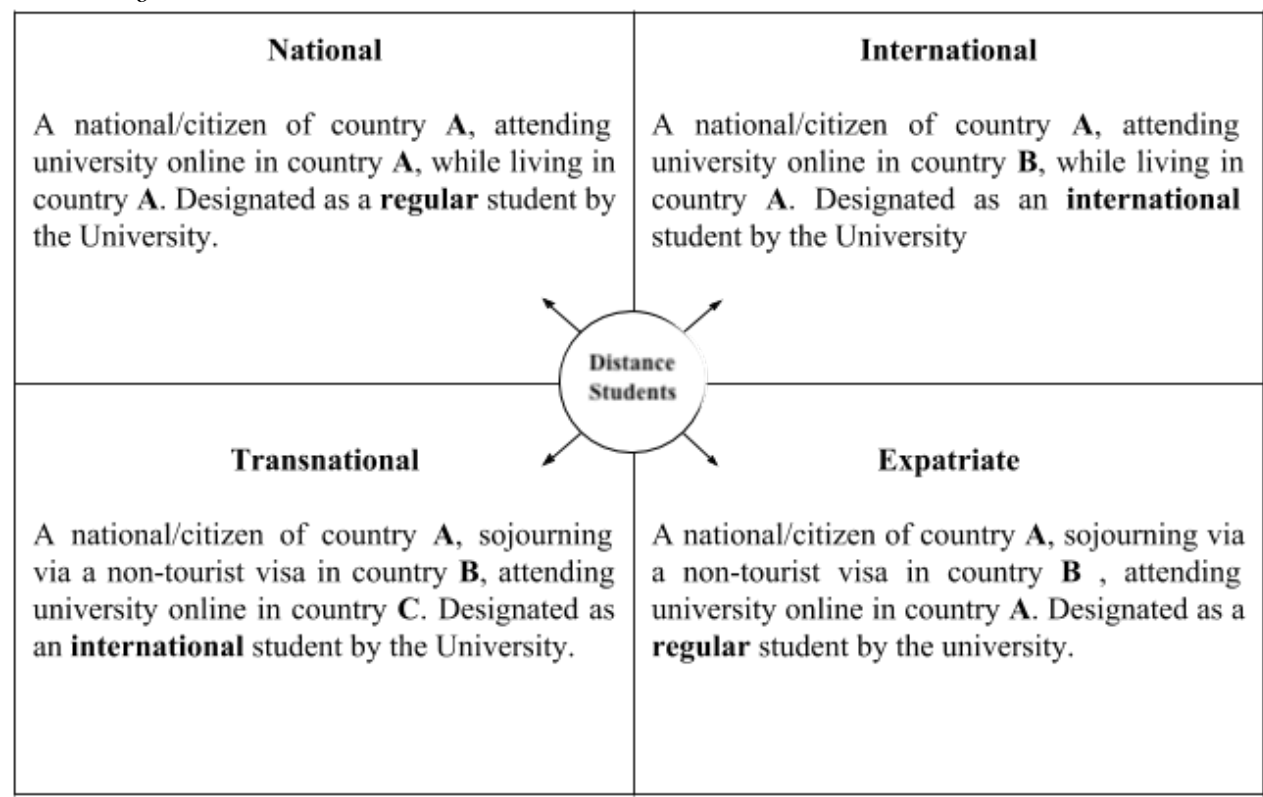

\section{Data Analysis and Saturation}

The range of participants can vary greatly in qualitative studies and is contingent upon the emerging nature of a study (Creswell, 2013, 2015). Therefore, while it can be hard to predict when there are "enough" participants (Crouch \& McKenzie, 2006), Fusch and Ness (2015) suggested that researchers simply need to be "explicit regarding how data saturation is reached" if being guided by data saturation (p. 1413). During analysis, the constant comparison method was used to combine coding and analysis simultaneously in order to develop and document emerging concepts (Kolb, 2012). By interview 9, the vast majority of ideas expressed by the participant coincided with existing codes (often verbatim) and themes that had been developed throughout the interview analyses. Homogenous groups may present relatively similar information and enable saturation more quickly (Guest et al., 2006). Therefore, given the homogeneity of participants (all western, mostly male, similar fields of study) and lack of new information at interview 10, data saturation was considered to have been reached and data collection was discontinued. 


\section{Participants}

Participants surfaced only from western, English speaking countries. An overview of their demographic and program characteristics is presented in Table 1, and their locations in Korea depicted in Figure 2. The 10 participants were interviewed over a three-month period. The sample population $(n=10)$ was predominantly composed of expatriate distance students $(80 \%)$, mostly male $(70 \%)$, mostly master's degree students $(60 \%)$, and represented only three western nationalities. The homogeneity of the profile gleaned here is not representative of the foreign-resident population as a whole (see MoJ, 2016; Shin \& Moon, 2019) and is discussed further in the limitations section.

Table 3

Participants and Programs Overview

\begin{tabular}{|c|c|c|c|c|c|c|c|c|}
\hline & Nat & Gen & Age & $\begin{array}{l}\text { Uni } \\
\text { Location }\end{array}$ & $\begin{array}{l}\text { Study } \\
\text { Level }\end{array}$ & Field or Program & $\begin{array}{l}\text { Degree } \\
\text { Cost }\end{array}$ & $\begin{array}{l}\text { Location in } \\
\text { Korea }\end{array}$ \\
\hline \multicolumn{9}{|c|}{ Expatriate Distance Students } \\
\hline 1 & USA & M & 45 & USA & MA & TESOL & 55,000 & Seoul \\
\hline 2 & USA & M & 36 & USA & $\mathrm{PhD}$ & $\begin{array}{l}\text { Educational } \\
\text { Leadership }\end{array}$ & 30,000 & Gunpo \\
\hline 3 & USA & $\mathrm{F}$ & 40 & USA & EdD & $\begin{array}{l}\text { Lit., Culture, \& } \\
\text { Language Ed. }\end{array}$ & 30,000 & Gwangju \\
\hline 5 & USA & M & 34 & USA & MA & TESOL & 30,000 & Jeju \\
\hline 6 & USA & M & 34 & USA & EdD & $\begin{array}{l}\text { Learning Design \& } \\
\text { Perf. Tech. }\end{array}$ & 30,000 & Incheon \\
\hline 7 & ENG & M & 33 & ENG & EdD & $\begin{array}{l}\text { Higher Ed } \\
\text { Administration }\end{array}$ & 30,000 & Gunpo \\
\hline 8 & $\mathrm{ENG}$ & $\mathrm{F}$ & 35 & ENG & MA & TESOL & 15,000 & Busan \\
\hline 9 & CAN & $\mathrm{F}$ & 25 & CAN & MA & TESOL & 20,000 & Busan \\
\hline \multicolumn{9}{|c|}{ Transnational Distance Students } \\
\hline 4 & USA & M & 42 & AUS & MA & Applied Linguistics & 26,000 & Incheon \\
\hline 10 & CAN & M & 56 & SCT & MA & TESOL & 10,000 & Seoul \\
\hline
\end{tabular}

\section{Procedures}

Interviews were scheduled and each interview question and sub questions were aligned with one of the four corresponding research questions. Iterative adjustments were made to sub questions where appropriate throughout the course of interviews. For example, variations about a student's GPA or semester length had wording added for equivalents in British programs such as modules, percentages, and distinctions. Since the researcher was based in Seoul, Korea, interviews were conducted in person with participants living 
in/around the capital metropolitan area $(n=6)$ whereas interviews with participants living in cities along the southern coast $(n=4)$ were conducted by VoIP software as a matter of practicality and convenience (see Figure 2 ). Each interview lasted around 60 minutes.

\section{Validation Strategies and Trustworthiness}

Each interview followed an interview protocol for uniformity prior to, during, and after the interview. Field notes were kept, as well as an audit trail that documented when and where raw data was collected, including interview and analysis notes, as well as chronicling the sequence in which categories, themes, definitions, and relationships were developed (Lincoln \& Guba, 1985). Initial (and iterative) drafts of the logic model were sent to participants as a means of member checking so that they could "judge the accuracy and credibility" of how their decision-making processes were interpreted throughout the analysis and subsequently constructed, providing the opportunity to offer additional insight or feedback before being finalized (Creswell, 2013, p. 252).

\section{Figure 2}

Map of South Korea and Participants' Locations

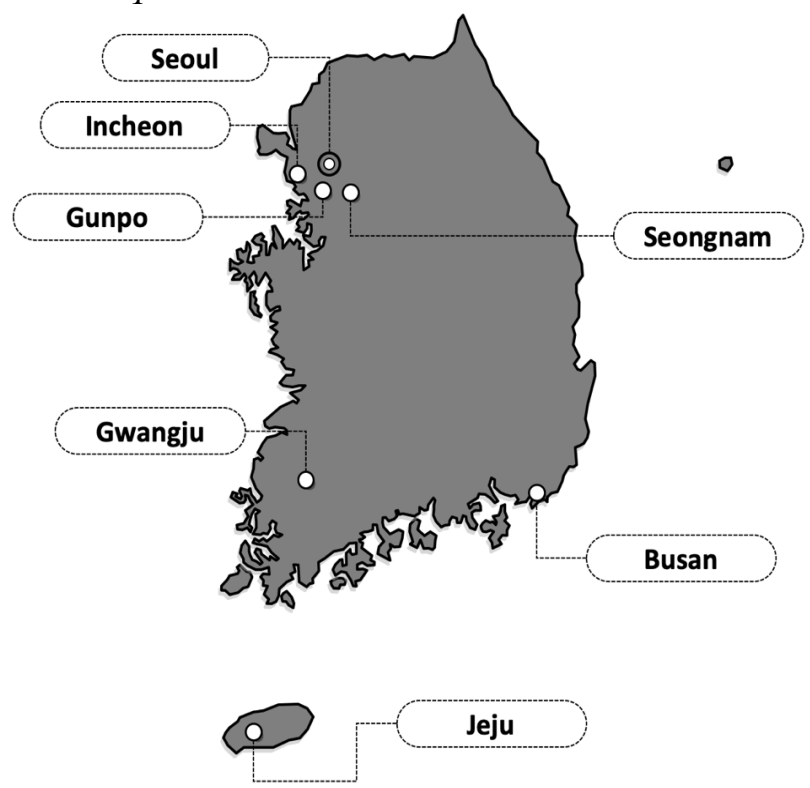

\section{Results}

Unlike the plethora of college choice models synthesized from samples of traditional high school students (or young adults) as first-time undergraduate college goers, participants in this study were nontraditional adult graduate students, and importantly, first generation immigrants in Korea. Most participants (80\%) were studying at "home" in their countries of citizenship with programs ranging in price from 10,000-55,000 USD. In order for all participants to work in Korea in their current professions, possessing an undergraduate education (at a minimum) was necessary both as an industry standard, and a requirement established by the Korean Immigration Office for most of their visas.

Three broad phases emerged from analyzing the interviews, which is generally similar with previous scholarship on college choice (see Vrontis et al., 2007). However, unlike an information gathering process which is often the first phase in the process, participants 
described an initiating event. This idea was prevalent when participants were asked why they decided to seek educational opportunities online, as well as the impetus for that decision at that specific point in time. Some initiating events were conditional in nature such as Participant 9 (Expatriate: Canada, F, 25, MA)'s where she stated an implicit contingency:

I kind of came to Korea thinking I will try this [teaching English]. And if I like it, then I'll get the master's degree. So, I came here with the intention of starting the master's degree if all went well, and all went well.

Or Participant 2 (Expatriate: USA, M, 45, MA) who needed to make a career change from the nightlife and entertainment industry in order to raise his young daughter. He recounted how a friend of his had presented him with a path to a different career that necessitated pursuing the degree:

Hey, if you're looking for a transition, I have a job at the university. We're looking to hire someone, I can get you in, but one of the, one of the conditions is, you got to start working on your MA immediately.

More notably among the vast majority of participants, however, was the theme of repatriation interwoven among the three categories of events that emerged.

\section{Repatriation as a Determinant}

The idea of repatriation is complex because on the one hand, some participants (Participant 2, 6, 10) considered their enrollment in an online program as a direct and calculated step towards reintegrating into the labor force in their home countries after having spent years abroad in Korea. For example, Participant 2 (Expatriate: USA, M, 45, MA) had gotten married, had a child, and explained rather strategically the calculus behind his decision:

I really wanted to move my family back to the United States... I saw that over 3500 administrative spots a year nationwide [in the U.S.], were going to under qualified applicants in administrative positions because they did not have doctorates and I identified that as an area where I would easily be able to move back with the credentials from the program, that I decided to choose and find a job.

Whereas for Participants 1, 3, 4, 5, 7, 8, 9, repatriation was a far more indefinite idea. Participant 6 (Expatriate: USA, M, 34, EdD) summarized this point rather well given the tenuous stability of being a foreign worker, and the related costs for his daughter's schooling since foreign children also do not necessarily have easy paths in the local educational system (see Greenholtz \& Kim, 2009):

We don't have any definite plans of going back. But I would say we have a general idea that, that's something that we'll need to do, especially with our daughter's schooling, and international school is quite expensive... but as far as a specific plan for that, there's nothing definite.

Participant 9 (Expatriate: Canada, F, 25, MA) similarly shared the idea of an eventual but indefinite return in the future: 
I foresee myself ending up in Canada, again one day. Um, I didn't know if that [an American] degree [taken online] would need to be assessed or not in Canada. So, I thought it would just be easier to just get something from Canada since I'm probably going to be going back to Canada in the future.

Figure 3

Life Events and Repatriation

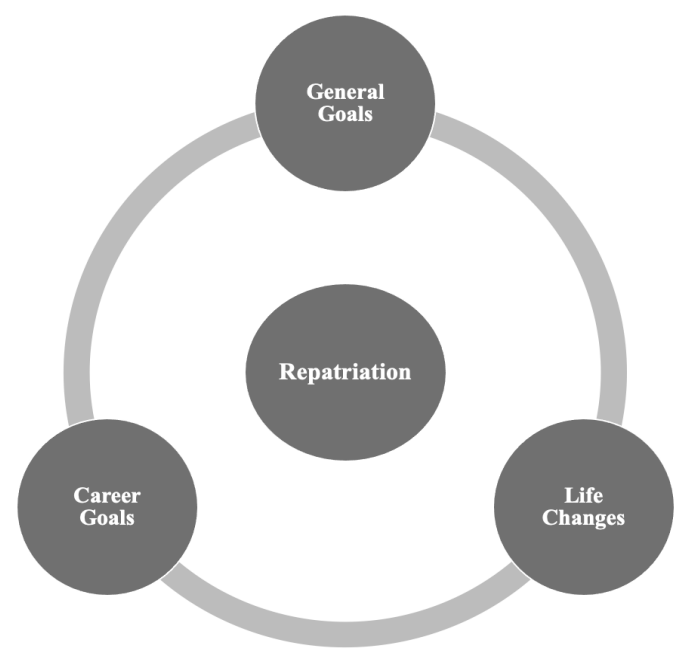

This indefinite nature can arguably be seen in the current length of their sojourn periods in Korea which, on average, is roughly 12.5 years. Moreover, even if repatriation was a clear and deliberate decision as was the case with Participant 2, 6, and 10, they ultimately never realized that goal. Thus repatriation as a determinant, at least for some, can be paradoxical and related to changing beliefs. Participant 2 (Expatriate: USA, M, 36, PhD) explained how his perspectives on "home" had shifted:

I was planning on gaining [higher education] certification to move my family back to the United States. But as my children have grown up here, my view on Korean education for young children has changed and I thought, is a place where I would prefer to raise my children. And as that perspective shifted, my perspective on my degree and the goals I wanted from it also shifted.

Participant 1 (Expatriate: USA, M, 45, MA), who eventually left Korea, did not return to his home country; rather he went on to pursue an additional master's degree in the UK in a face-to-face program, explaining that "I had been here for eight years, and it was just time to try something [new], to, I just needed a break from [Korea] for me." Thus in addition to repatriation, the degree also served as a more general exit vehicle to transition to life elsewhere.

Other participants mentioned the need for higher qualifications to pursue more advantageous local work opportunities (Participant 5, 8), though these motivations were not exclusive to work in Korea. Nevertheless, while repatriation as theme was not the sole motivator for pursuing distance degrees in students' home countries (or for UK based degrees for transnational distance students in this study), repatriation was a constant thread among 
the three broad event categories discussed by participants (general goals, professional/career goals, life changes). Thus, while the initiating events identified by participants in this study fall in line with the motivations of adult nontraditional distance students (see Lansing, 2017), repatriation may stand out as a factor unique to foreign resident populations, and as a theme, plays several roles: motivation, event, and process. The definite or indefinite desire to repatriate aside, students needed certain conditions to be met in order to even pursue the degree. The interconnectedness of the relationships and repatriation as a determinant is illustrated in Figure 3.

\section{Flexibility \& Visa Status}

Similar to many nontraditional students, participants in this sample needed to work in order to earn a salary, support themselves and family members, children, etc. In the words of Participant 6 (Expatriate: USA, F, 34, EdD), this requirement was clear:

For me, basically, online is the only option, I guess, as far as like time. So, as I mentioned, I've got a daughter, I'm a pretty active dad, and time wise, trying to go to any sort of class in person would be a stretch, and my wife is wonderful and supportive. But, I mean, I still have to be able to work full time, like if I schedule available during the day, and I've got responsibilities in the evening. So, really, time wise, doing an asynchronous online program would be basically the best for me.

An additional consideration as foreign workers, however, was the need to stay employed to maintain a legal visa status. There was one exception to this general condition with Participant 1 who was ethnically Korean and able to obtain a heritage visa that afforded him the right to live and work in Korea without visa sponsorship. While Participant 2 had earned permanent residency, Participant 4 had a marriage visa, and Participant 6 had just earned a non-permanent residency visa, this was not the case upon arrival. Thus, while nontraditional students and adults may often seek out the flexibility distance programs in order to keep working, for expatriate distance students, distance education also facilitated maintaining legal visa status. The search process and its constraints and information sources are illustrated in Figure 4. Nevertheless, explaining why they chose distance programs outside of Korea was a more complicated issue.

\section{Educational Ecosystem: The Path of Least Resistance}

The decision-making process of the participants relied heavily on finding out about their programs by word of mouth or familiarity. All of the participants described applying to/enrolling in their programs so nonchalantly that this researcher found it genuinely surprising. While getting information from friends, family members, or coworkers, is not surprising and common among college choice models (see Lansing, 2017; Vrontis, 2007), the lack of further information gathering highlighted a proverbial "path of least resistance" for many of the participants in this sample. Participant 3 (Expatriate: USA, F, 40, EdD) explained that a friend of hers originally "mentioned that she had gotten her master's in IST by distance from Indiana University, and was doing a masters in LCLE by distance through Indiana. So, I talked to her and found out about this particular master's program." Largely for this reason, she enrolled, graduated, and ultimately "heard from my advisor, my, well, the head of the department at the time, that they were thinking of creating a distance EdD program, and would I be interested? So, I immediately responded, yes, I'm interested.” 
Figure 4

Search Constraints and Information Sources

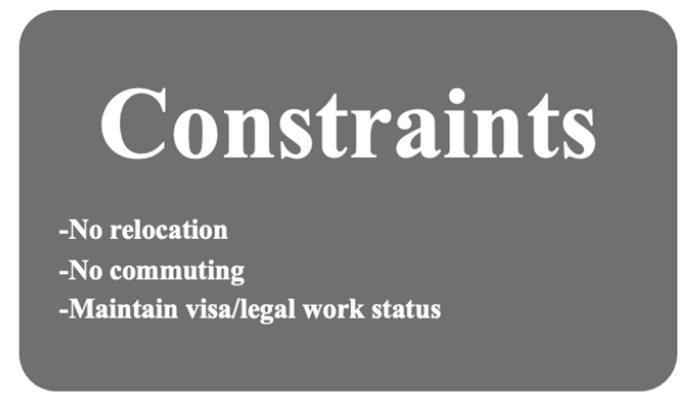

\section{Info Sources}

-Internet

-Friends

-Word of mouth

-Professional Associations

-Alma mater

This experience was nearly identical for Participant 6 who had completed his masters at a distance while living in Korea and then by chance, when a doctoral program became available in the same department, he decided to pursue it. Participant 8 (Expatriate: England, F, 35, MA) had a similarly uninvolved information gathering stage where:

I met a friend who introduced the course to me. Um, but I was, I was trying to think ahead, and I wasn't sure how things would turn out. And I was back in the UK [on holiday], and I just decided to apply for the October 2018 intake. And I got accepted the next day. It was really quick.

Figure 5

Push and Pull Factors
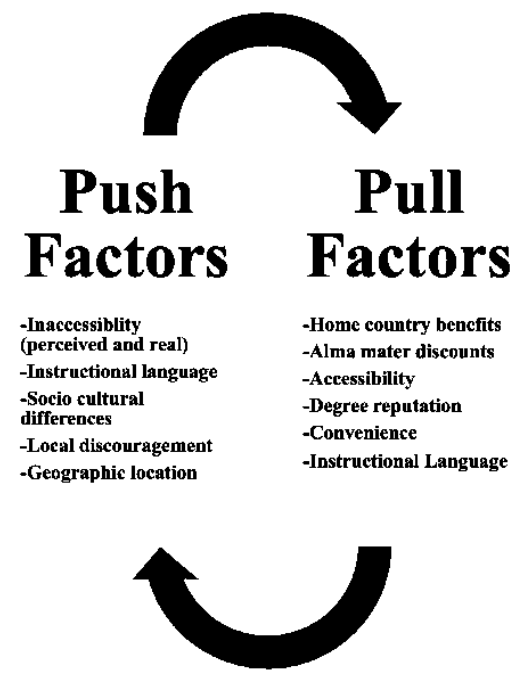

Participant 10 (Transnational: Canada/Scotland, M, 56, MA) had a similar experience with the unexpected ease of applying:

I actually, I just applied to the one and they accepted me...there was no resistance from them. I didn't have to pitch myself. I just, I had my, my recommendation letters, you 
know, maybe I did a good job of that...so I don't, I don't know exactly why they were, why they rolled over so quickly on my application [laughing]. But yeah, it was just like, oh, yeah, you can come. And that was it.

All 10 participants in this study applied only to a single university, and equally relevant, did not actually consider more than one institution with the exception of Participant 2 whose decision-making process followed more conventional college choice models (see Vrontis et al., 2007). When participants were asked about why they did not choose local Korean programs (as well as local transnational programs), factors emerged that pushed them away from local programs, as well as ones that pulled them back home beyond just the idea of repatriation. What stood out among the accounts of expatriate distance students was not any individually unique pull factor, but rather the collective sum of interdependent pull factors, or what this researcher posits is an educational ecosystem. The push and pull factors are illustrated in Figure 5.

\section{Discussion}

Iloh (2018) noted that there has often been a "lack of nuance perspective and the square peg in a round hole view of post-traditional students" which is "rooted in the historic youth centricity of postsecondary education" (p. 232). Moreover, higher education policy is commonly driven by traditional four-year residential educational experiences despite this experience becoming far more varied today. Participants highlighted various push factors that steered them away from taking advantage of local Korean programs such as linguistic inaccessibility to both information about programs and classroom instruction. For example, even though Participant 4 (Expatriate: USA, M, 42, MA) had been living in Korea for around 12 years when he started his master's program in Australia, he explained how information accessibility was a barrier:

Basically, a part of it was, I didn't know anything about it. I didn't know where to begin. I didn't know who to talk to, where to go. Accessibility was a big part of it. And then, you know, stuff that I did find when I would do a search for it online would take me to page all in Korean. And it's like, all right, well, if the entry point is this [difficult], then what's it going to be, you know, like in the classroom. Accessibility was a big part.

It must be noted that despite the perception of linguistic inaccessibility, there are large public and private universities (particularly in the capital-metropolitan region) that enroll hundreds to thousands of foreign students annually through official exchange programs, degree seeking programs, and short term study programs. As a result, information about these programs is readily available in English on their respective websites. Moreover, both TESOL and Applied Linguistics master's (a common program among this sample) are available with classes offered in both English and Korean. Therefore, while the information may be available, foreign residents may not know how to access it as expressed by Participant 4. Participant 9 (Expatriate: Canada, F, 25, MA) had otherwise never really realized that studying in Korea was a possibility:

I just didn't know that I could do that [study] in Korea- I'd never met anyone who had studied abroad in Korea, so I had no concept of the programs that were available to me, and naively, without doing any research, I assumed that I would need to speak 
Korean which I know doesn't make sense. But I just, I just never even thought about that, and then when I came to Korea, I learned that there are programs, I met some university students who were studying here in Busan for a little bit and then moved to Seoul to pursue their masters or PhD programs.

Other participants had concerns over traditional/Confucian teaching methods, different cultural perceptions of the classroom, and degree validity outside of Korea. While each concern is individually recognizable, the language of instruction cannot be separated from the host country's national language, just as the Confucian cultural heritage of Korea is inseparable from how classrooms function. Participant 2 (Expatriate: USA, M, 36, PhD) explained this conflict between the local educational tradition and his own habitus:

The Korean nature of education is based in the in Confucian hierarchy ideals, where the teacher is the purveyor of knowledge, and the students are meant to sit and listen, this is conducive to the traditional lecture format. And while lectures have their place, I, I myself work much better in a more collaborative and student-centered environment... I didn't think that studying in Korea was the right fit for me.

Participant 8 (Expatriate: England, F, 35, MA) shared a skepticism related to instructional language since it is not uncommon for Korean faculty who speak English to teach classes in Korean even there are only one or two non-Korean speaking students:

It [class] was supposedly in English, but I didn't really believe that they would teach most of the lectures in English. And then there was one more but, the, it was a university I had not heard of, I think it was a maritime university, so it just made me, I couldn't really find that much information for courses in Busan, so it kind of put me off and I wasn't sure I would enjoy the Korean style of lectures and assessment.

Furthermore, participants also noted how they were pushed away from Korean universities by discouragement from Korean friends, colleagues, or hiring managers. Participant 7 (Expatriate: England, M, 33, EdD) rather clearly articulated the difficulty of this unexpected push factor:

I was given the impression from people even within those [Korean] programs, that they may not carry the same weight as if I had the qualification from, let's say, back in the UK or Europe...and also Korean friends, who..., it's been the ones who've gotten the PhDs from other countries who have managed to get the position they wanted. Whereas the ones who got them domestically, have struggled much more...and as I said, actually being told by people working in higher education institutions that they would actually potentially discriminate against domestic doctoral programs.

When participants discussed their reasons for choosing the universities they enrolled in, the lack of actual information gathering for most participants might be explained by the concept of an educational ecosystem at play. For example, the ability to receive in-state tuition (in the United States) despite living abroad, alumni tuition discounts at alma maters, administrative ease due to prior enrollment, former master's students pursuing doctorates in the same program, or enrolled in a sequential degree pathway (i.e., EdS to PhD). The lack of 
any overt obstacles or barriers, whether linguistic, knowledge-based, or administrative, simply made it easy to access information online, and to apply and enroll without much effort.

Rather than performing exhaustive searches and discriminant choosing, participants simply turned to an ecosystem where information was accessible, where they had an intrinsic background knowledge, to other foreign residents with pertinent information, or to where they had prior educational experience. This ecosystem effect might reasonably explain the lack of effort that the majority of the participants invested in seeking out where to do a graduate degree. Iloh (2018) called the absence of such information an information desert and ascribed it to a "failure of society, not particular communities, to democratize and make college information accessible across diverse communities and contexts" (p. 236). In this sense, there is much potential for improvement in Korea to provide information to its increasingly more diverse immigrant population (Shin \& Moon, 2019).

\section{Implications}

Korean universities (and others elsewhere around the world) may not necessarily consider adult, nontraditional, foreign born, first generation immigrants as potential students and as a result, do not market to them or include them in higher education growth strategies. By contrast, there has been a considerable effort to recruit traditional and "international" students from abroad in Korea (see Choi et al., 2019; Jon et al., 2014). Thus, rather than only looking inward at a growing foreign born adult population (see MoJ, 2016; Shin \& Moon, 2019), university policy in Korea may benefit from adapting policies and conventional view of students in response to significant changes in demographic trends, immigration, and the broader effects of globalization in the 21 st century. By not recognizing the admittedly niche population (especially in Korea) of nontraditional or post traditional students, Korean universities are losing numerous opportunities to internationalize from within, generate revenue, and to meet the needs of an increasingly diverse society. Of course, this phenomenon is not limited to Korea; any country could benefit from re-considering how immigrant populations are considered in higher education strategies.

While an information desert (see Iloh, 2018) in Korea was an experience shared by participants in this study, these participants ultimately overcame it by seeking out distance programs abroad. As first-generation adult immigrants (and admittedly privileged ones with the means and resources), the convenience of the medium and information accessibility made the ability to apply and enroll a matter of simplicity and convenience. For example, Participant 1(Expatriate: USA, M, 45, MA) ended up choosing a university in his hometown of Los Angeles despite living in Korea. Participant 3 (Expatriate: USA, F, 40, EdD) completed a second master's degree while currently working on a doctorate at the same university. Participant 6 (Expatriate: USA, M, 34, EdD) did his bachelor's degree while living in Florida, and later completed a master's program at the same university while living in Korea. When he started looking at doctoral degrees, he found out that he could continue in the same program without having to expend much effort:

It's the same professors that I had before, it's like literally the same people I took classes with two years ago, so like I already know them, like I got the person in charge of the program to write a recommendation letter, because I did my masters there... all my documents, everything is registered through my parents address so that I was able to maintain in-state residency for tuition purposes. So, I was particular to that...and had the advantage of making it really easy to get transcripts and all those 
sorts of things. So, and they were really helpful with assisting me and applying and getting all the documents that I needed. So, that was how I chose it.

Take, for example, the Apple ecosystem, which consists of various software platforms, hardware devices, and internet services that create a seamless and efficient user experience. On the one hand, the convenience and benefits of investing fully in the ecosystem is compelling because it is simple and easy to use and built on cross-platform compatibility. On the other, leaving it for another competing vendor is complicated and/or difficult since there may be no analogous components. Moreover, the switch is likely costly in terms of time and money. Staying within the ecosystem is simply the path of least resistance.

Thus, for expatriate distance students, the pull or appeal of the home country educational ecosystem (alumni discounts, in-state tuition fees, prior enrollment), though simple as an extension of their habitus, is arguably more pronounced as first-generation immigrants. Moreover, the appeal may be even stronger when there are obstacles or barriers (e.g., linguistic, socio cultural) that hinder access to entering the local educational landscape. For the expatriate and transnational distance students in this sample, the perceived and actual complexity/difficulty of switching into the local Korean educational ecosystem, despite years of residency and indefinite plans to stay, might make the characterization of their "choice" more accurately a non-decision.

When specifically taking into account the context of first-generation adult immigrants in a foreign society, the local choice set may be considerably narrower or nonexistent due to inequities in background knowledge of universities/programs and linguistic abilities, and an education system that does not necessarily recognize non-traditional students. As a result, distance education opportunities in one's home country, enabled by modern information and communications technology, may be a practical way to overcome or compensate for these obstacles. For example, barriers for UK nationals who immigrate to Canada (or vice versa) are arguably inconsequential given a shared L1 and socio-cultural traditions related to education, unlike the cultural and linguistic differences between western immigrants in Korea.

One consequence of transnational access to distance education is the financial loss to the local economy, and a participatory loss to local academia, especially for doctoral students. Participants in this study in some cases were paying up to 50,000 USD for a master's degree or paying around 30,000-40,000 USD for doctoral programs (see Table 3). While these costs are overt, there were also covert costs for students who were required to complete residency requirements which cost thousands of dollars in airfare and lodging. Moreover, doctoral students in this sample had also completed their master's degrees at a distance while living in Korea, highlighting how significant the financial and intellectual investment in their education was, and the larger scope of financial loss to the local economy.

Local universities could benefit by adapting their recruiting strategies to first and foremost recognize changing demographic trends related to globalization, and specifically by considering adult foreign residents as potential students. Moreover, local universities could benefit by offering distance programs in languages other than Korean (as is common for certain face-to-face programs) since these types of students also need to maintain legal visa statuses. In Korea over the last 35 years, the foreign-born immigrant population has grown from 30,000 to over 2.5 million today (see Shin \& Moon, 2019).

If universities were to market and recruit prospective adult immigrant students early on in their sojourns in Korea through local district offices, local government community centers, education fairs, or larger governmental organizations like the Seoul Global Center 
or even the Immigration Office itself, they might be able to bring potential students into the local university ecosystem, and establish convenient and simpler administrative pathways for pursuing certifications or degrees, just as their native born counterparts conventionally do. Moreover, Global Centers in Seoul and other large cities (e.g., Busan, Incheon), though relatively young, have steadily added services over the last 10 years (SGC, n.d.) and higher education counseling may be worthy of inclusion to their current integration strategies moving forward.

\section{Conclusion}

The decision to enroll in distance programs in one's home country or elsewhere abroad while living in a foreign country is multifaceted. Although repatriation was an everpresent underlying thread interwoven among life changes, career, and general goals, it was not necessarily a disproportionately influential determinant. Moreover, while expatriate and transnational distance students wanted to keep working in much the same vein as nontraditional students, they were also dependent on their employment to maintain visa sponsorship and legal visa status. This dependency typically necessitated distance programs to achieve both of those goals. Though these participants wanted to pursue further education, access to local programs as foreign-born adult immigrants was often inaccessible, despite lengthy periods of sojourn.

This study contributes to the college choice literature by explicitly investigating expatriate and transnational distance students, and specifically those within the context of Korea. Certain findings presented here confirm other findings in the literature base (e.g., Lansing, 2017) or certain aspects of theoretical models (e.g., Iloh, 2018), but this paper presents repatriation as a prevalent theme as a motivational factor for western, firstgeneration, adult-immigrant, graduate-distance students to seek out distance programs at home. Like any study, the findings should be considered judiciously when compared to other populations. The primary limitation is the lack of diversity among participants. Though the number of participants in qualitative studies can be small when the sample consists of relatively homogenous participants (Crouch \& McKenzie, 2006; Guest et al., 2006); the nationalities of participants represent a minority among the immigrant population as a whole which is predominantly Chinese, or from East Asia, Eurasia, and Southeast Asia. Their views likely do not necessarily reflect the views of this population as a whole, let alone the immigrant community at large. Nevertheless, there are numerous opportunities for future research.

Similar college choice or grounded theory studies can be conducted in other countries or regions with different groups of foreign nationals to explore the complexity in the decision-making process of adult immigrant graduate students, as well as the development and evaluation of university policies that are designed to recruit such students in the future. This line of inquiry would be useful since educational attainment studies on immigrants typically revolve around 1.5 or 2 nd generation immigrants rather than first (e.g., van de Werfhorst \& Heath, 2019). Further, given the difficulty of recruiting a more diverse participant pool, researchers might pursue a top-down approach where they can identify expatriate and transnational distance students at their own universities through departmental databases.

Quantitative approaches that can more rigorously analyze contextually specific relationships, motivations, or determinants through surveys or questionnaires such as the Traditional College Choice Scale (TCC), Distance College Choice Scale (DCC) (Lansing, 2017), or Arora's (1982) Involvement with Education Response (IE-R) and Situational (IE- 
S) scales could be useful. Participants in this study were all typical graduate students with relatively high GPAs or distinctions (see Colorado \& Eberle, 2010), and had completed multiple graduate degrees in certain cases.

Future research into the retention or attrition rates of expatriate and transnational distance students would yield complementary data to the distance education literature which is often nationally or homogeneously sampled. It would also be beneficial to investigate the scope of the expatriate and transnational distance student phenomenon in terms how many adult foreign residents pursue local opportunities in proportion to the ones who take up distance programs in their home countries or abroad, and also in relation to the relative socio cultural/linguistic differences between first generation immigrants and the host country. In short, there are plenty of avenues and opportunities of inquiry to keep researchers busy in the transnational education space (Wilkins, 2016).

\section{References}

Abubakar, B., Shanka, T., \& Muuka, G. N. (2010). Tertiary education: An investigation of location selection criteria and preferences by international students - the case of two Australian universities. Journal of Marketing for Higher Education, 20, 49-68. https://doi.org/10.1080/08841241003788052

Allen, I. E., Seaman, J., Poulin, R., \& Straut, T. T. (2016). Online report card: Tracking online education in the United States. Babson Survey Research Group. http://onlinelearningsurvey.com/reports/onlinereportcard.pdf

Andrews, T., \& Tynan, B. (2010). Why the student voice? The case for investigating the distance learners' experience of ICT in distance education. In Proceedings ASCILITE 2010: 27th Annual Conference of the Australasian Society for Computers in Learning in Tertiary Education: Curriculum, Technology and Transformation for an Unknown Future (pp. 60-64). University of Queensland.

Arora, R. (1982). Validation of an S-O-R model for simulation, enduring, and responsecomponents of involvement. Journal of Marketing Research, 19, 505-516. https://doi.org/10.1177/002224378201900411

Barbour, M. K. (2017). K-12 online learning and school choice: Growth and expansion in the absence of evidence. In R.A. Fox \& N.K. Buchanan (Eds.), The Wiley handbook of school choice (pp. 421-440). Wiley Blackwell.

Beech, S. E. (2018). Adapting to change in the higher education system: International student mobility as a migration industry. Journal of Ethnic and Migration Studies, 44, 610-625. https://doi.org/10.1080/1369183X.2017.1315515

Bers, T. H., \& Smith, K. (1987). College choice and the nontraditional student. Community College Review, 15, 39-45. https://doi.org/10.1177/009155218701500106

Binsardi, A., \& Ekwulugo, F. (2003). International marketing of British education: Research on the students' perception and the UK market penetration. Marketing Intelligence É Planning, 21, 318-327. http://doi.org/10.1108/02634500310490265

Bodycott, P. (2009). Choosing a higher education study abroad destination. Journal of Research in International Education, 8, 349373. https://doi.org/10.1177/1475240909345818

Braun, V., \& Clarke, V. (2006). Using thematic analysis in psychology. Qualitative Research in Psychology, 3, 77-101. http://doi.org/10.1191/1478088706qp0630a 
Cha, M., \& Chang, W. (2009) Learning through working: A case study of Chinese college students in South Korea. Asia Pacific Journal of Education, 29, 311 320. https://doi.org/10.1080/02188790903092803

Chapman, D. W. (1981). A model of student college choice. The Journal of Higher Education, 52, 490-505. https://doi.org/10.1080/00221546.1981.11778120

Chapman R. (1984). Toward a theory of college choice: A model of college search andchoice behaviour. University of Alberta Press.

Chen, L. H. (2007). East-Asian students' choice of Canadian graduate schools. International Journal of Educational Advancement, 7, 271306. https://doi.org/10.1057/palgrave.ijea.2150071

Choi, J., Tatar, B., \& Kim, J. (2019). Bilingual signs at an 'English only' Korean university: Place-making and 'global' space in higher education. International Journal of Bilingual Education and Bilingualism, 1-14. https://doi.org/10.1080/13670050.2019.1610353

Colorado, J. T., \& Eberle, J. (2010). Student demographics and success in online learning environments. Emporia State Research Studies, 46, 4-10. https:// esirc.emporia.edu/bitstream/handle/123456789/380/205.2.pdf

Creswell, J. W. (2013). Qualitative inquiry \& research design: Choosing among five approaches. Sage.

Creswell, J. W. (2015). Educational research: Planning, conducting, and evaluating quantitative and qualitative research. Pearson/Merrill Prentice Hall.

Crouch, M., \& McKenzie, H. (2006). The logic of small samples in interview-based qualitative research. Social Science Information, 45, 483-499. https://doi.org/10.1177/0539018406069584

El Nemar, S., \& Vrontis, D. (2016). A higher education student-choice analysis: The case of Lebanon. World Review of Entrepreneurship, Management and Sustainable Development, 12, 337-351. https://doi.org/10.1504/WREMSD.2016.07497

Ewing, R., Schroeer, W., \& Greene, W. (2004). School location and student travel analysis of factors affecting mode choice. Transportation Research Record, 1895, 55-63. https://doi.org/10.3141/1895-08

Fang, W., \& Wang, S. (2014). Chinese students' choice of transnational higher education in a globalized higher education market: A case study of W University. Journal of Studies in International Education, 18, 475-494. https://doi.org/10.1177/1028315314523989

Fuller, W. C., Manski, C. F., \& Wise, D. A. (1982). New evidence on the economic determinants of postsecondary schooling choices. Journal of Human Resources, 17, 477-498. http://doi.org/10.2307/145612

Fusch, P. I., \& Ness, L. R. (2015). Are we there yet? Data saturation in qualitative research. The Qualitative Report, 20, 1408-1416. http://www.nova.edu/ssss/QR/QR20/9/fusch1.pdf

Gatfield, T., \& Chen, C. (2006). Measuring student choice criteria using the theory of planned behaviour: The case of Taiwan, Australia, UK, and USA. Journal of Marketing for Higher Education, 16, 77-95. https://doi.org/10.1300/J050v16n01_04

Gemmell, I., \& Harrison, R. (2017). A comparison between national and transnational students' access of online learning support materials and experience of technical difficulties on a fully online distance learning master of public health programme. Open Learning, 32, 66-80. https://doi.org/10.1080/02680513.2016.1253463 
Greenholtz, J., \& Kim, J. (2009). The cultural hybridity of Lena: A multi-method case study of a third culture kid. International Journal of Intercultural Relations, 33, 391398. http://doi.org/10.1016/j.ijintrel.2009.05.004

Griffin, K., Del Pilar, W., McIntosh, K., \& Griffin, A. (2012). "Oh, of course I'm going to go to college": Understanding how habitus shapes the college choice process of Black immigrant students. Journal of Diversity in Higher Education, 5, 96-1 1. https://doi.org/10.1037/a0028393

Guest, G., Bunce, A., \& Johnson, L. (2006). How many interviews are enough? An experiment with data saturation and variability. Field Methods, 18, 59-82. https://doi.org/10.1177/1525822X05279903

Hanson, K. H., \& Litten, L. H. (1982). Mapping the road to academe: A review of research on women, men, and the college-selection process. In P. J. Perun (Ed.), The undergraduate woman: Issues in educational equity (pp.73-98). Lexington Books.

Harris, H. S., \& Martin, E. W. (2012). Student motivations for choosing online classes. International Journal for the Scholarship of Teaching and Learning, 6. https://doi.org/10.20429/ijsotl.2012.060211

Harrison, R. A., Harrison, A., Robinson, C., \& Rawlings, B. (2018). The experience of international postgraduate students on a distance-learning programme. Distance Education, 39, 480-494. https://doi.org/10.1080/01587919.2018.1520038

Hossler, D., \& Gallagher, K. (1987). Studying student college choice: A three-phase model and implications for policymakers. College and University, 62, 207-221. https://eric.ed.gov/?id=EJ354226

Hossler, D., Schmit, J., \& Vesper, N. (1999). Going to college: How social, economic, and educational factors influence the decisions students make. JHU Press.

Iloh, C. (2018). Toward a new model of college "choice" for a twenty-first-century context. Harvard Educational Review, 88, 227-244. https://doi.org/10.17763/1943$\underline{5045-88.2 .227}$

Jackson, G. A. (1982). Public efficiency and private choice in higher education. Educational Evaluation and Policy Analysis, 4, 237-247. https://doi.org/10.3102/01623737004002237

Jaggars, S. S. (2014). Choosing between online and face-to-face courses: Community college student voices. American Journal of Distance Education, 28, 27-38. https://doi.org/10.1080/08923647.2014.867697

Jon, J. E., Lee, J. J., \& Byun, K. (2014). The emergence of a regional hub: Comparing international student choices and experiences in South Korea. Higher Education, 67, 691-7 10. http://doi.org/10.1007/s10734-013-9674-0

Joseph, M., \& Joseph, B. (2000). Indonesian students' perceptions of choice criteria in the election of a tertiary institution: Strategic implications. International Journal of Educational Management, 14, 40-44. https://doi.org/10.1108/09513540010310396

Kim, S. K. (2018). Illegitimate elites and the politics of belonging at a Korean university. Journal of Korean Studies, 23, 175-202. http://doi.org/10.1215/21581665-4339107

Kim, D., Bankart, C. A., Jiang, X., \& Brazil, A. M. (2018). Understanding the college choice process of Asian international students. In Y. Ma \& M. A. Garcilla-Murillo (Eds.) Understanding international students from Asia in American universities (pp. 1541). Springer International Publishing. 
Kolb, S. M. (2012). Grounded theory and the constant comparative method: Valid research strategies for educators. Journal of Emerging Trends in Educational Research and Policy Studies, 3, 83-86. https://hdl.handle.net/10520/EJC135409

Kosmützky, A., \& Putty, R. (2016). Transcending borders and traversing boundaries. Journal of Studies in International Education, 20, 8-33. https://doi.org/10.1177\%2F 1028315315604719

Lam, J., Ariffin, A. A. M., \& Ahmad, A. H. (2011). Edutourism: Exploring the push-pull factors in selecting a university. International Journal of Business $\mathscr{E}^{\circ}$ Society, 12, 63-78. http://shdl.mmu.edu.my/id/eprint/3792

Lansing, J. (2017). A new model of college choice for distance learners. Journal of Educational Technology Systems, 45, 365-389. https://doi.org/10.1177/0047239516673183

Levers, M. J. D. (2013). Philosophical paradigms, grounded theory, and perspectives on emergence. SAGE Open, 3, 1-6. http://doi.org/10.1177/2158244013517243

Li, M., \& Bray, M. (2007). Cross-border flows of students for higher education: Pushpull factors and motivations of mainland Chinese students in Hong Kong and Macau. Higher Education, 53, 791-818. http://doi.org/10.1007/s10734-005-5423-3

Lincoln, Y. S., \& Guba, E. G. (1985). Naturalistic inquiry. Sage Publications.

Madge, C., Raghuram, P., \& Noxolo, P. (2015). Conceptualizing international education: From international student to international study. Progress in Human Geography, 39, 681-701. https://doi.org/10.1177/0309132514526442

Manski, C. F., \& Wise, D. A. (1983). College choice in America. Harvard University Press. Maringe, F., \& Carter, S. (2007). International students' motivations for studying in UK $\mathrm{HE}$ : Insights into the choice and decision making of African students. International Journal of Educational Management, 21, 459-475. http://doi.org/10.1108/09513540710780000

Mazzarol, T., \& Soutar, G. N. (2002). "Push-pull” factors influencing international student destination choice. International Journal of Educational Management, 16, 82-90. https://doi.org/10.1108/09513540210418403

McMahon, M. E. (1992). Higher education in a world market: An historical look at the global context of international study. Higher Education, 24, 465-482.

https://www.jstor.org/stable/3447582

Ministry of Justice [MoJ]. (2016). Korean Immigration Service statistics. 1-1055. http://www.immigration.go.kr/HP/COM/bbs_003/BoardList.do?strNbodCd=noti 0096\&strOrgGbnCd=104000\&strFilePath=imm/\&strRtnURL=IMM 6050\&strNb odCdGbn=\&strType $=$ \&strAllOrgYn $=\mathrm{N}$

Özoğlu, M., Gür, B. S., \& Coşkun, İ. (2015). Factors influencing international students' choice to study in Turkey and challenges they experience in Turkey. Research in Comparative and International Education, 10, 223-237.

https://doi.org/10.1177/1745499915571718

Padlee, S. F., Kamaruddin, A. R., \& Baharun, R. (2010). International students' choice behaviour for higher education at Malaysian private universities. International Journal of Marketing Studies, 2, 202-211. http://citeseerx.ist.psu.edu/viewdoc/download?doi=10.1.1.825.3679\&rep=rep1\&ty $\mathrm{pe}=\mathrm{pdf}$

Panda, S. (2005). Higher education at a distance and national development: Reflections on the Indian experience. Distance Education, 26, 205225. http://doi.org/10.1080/01587910500168868 
Park, S. J. (2019). The globalization of Korean universities and Chinese students: A comparative analysis between universities in Seoul and a provincial city. Korean Anthropology Review, 3, 253-291. http://hdl.handle.net/10371/146918

Pérez, P. A. (2010). College choice process of Latino undocumented students: Implications for recruitment and retention. Journal of College Admission, 206, 21-25. http://hdl.handle.net/10919/86963

Pimpa, N. (2005). Marketing Australian universities to Thai students. Journal of Studies in International Education, 9, 137-146. https://doi.org/10.1177/1028315305274851

Pollock, D. C., \& Van Reken., R. (2009). Third culture kids: Growing up among worlds. Nicholas Brealey Publishing.

Punj, G. N., \& Staelin, R. (1978). The choice process for graduate business schools. Journal of Marketing Research, 15, 588-598. https://doi.org/10.1177/002224377801500408

Rensimer, L. (2016). International higher education for whom? Expatriate students, choicemaking and international (im) mobility in the Northern United Arab Emirates. Forum for International Research in Education, 3, 7996. http://dx.doi.org/10.18275/fire201603021092

Rice, K. L. (2006). A comprehensive look at distance education in the K-12 context. Journal of Research on Technology in Education, 38, 425448. https://doi.org/10.1080/15391523.2006.10782468

Roblyer, M. D. (1999). Is choice important in distance learning? A study of student motives for taking Internet-based courses at the high school and community college levels. Journal of Research on Computing in Education, 32, 157-171. https://doi.org/10.1080/08886504.1999.10782621

Schwartz, J. B. (1985). Student financial aid and the college enrollment decision: The effects of public and private grants and interest subsidies. Economics of Education Review, 4, 129-144. https://doi.org/10.1016/0272-7757(85)90055-X

Seoul Global Center [SGC]. (n.d.). Seoul Global Center. http://global.seoul.go.kr/

Sewell, W. H., \& Shah, V. P. (1968). Social class, parental encouragement, and educational aspirations. American Journal of Sociology, 73, 559-572. https://www.jstor.org/stable/2775558

Shanka, T., Quintal, V., \& Taylor, R. (2005). Factors influencing international students' choice of an education destination-A correspondence analysis. Journal of Marketing for Higher Education, 15, 31-46. https://doi.org/10.1300/J050v15n02_02

Shin, G. W., \& Moon, R. J. (2019). Korea’s migrants: From homogeneity to diversity: An Asian survey special section. Asian Survey, 59, 595-606. https://doi.org/10.1525/as.2019.59.4.595

Stewart, W. H. (2017). Recognizing the expatriate and transnational distance student: A preliminary demographic exploration in the Republic of Korea. Open Praxis, 9, 463481. https://openpraxis.org/ openprax/index.php/OpenPraxis/article/view/677

Stewart, W. H. (2019). The complexity of transnational distance students: A review of the literature. Open Praxis, 11, 23-39. https://www.openpraxis.org/index.php/OpenPraxis/article/view/923

Stewart, W. H. (2020). The expatriate and transnational distance student phenomenon: A multicase study of Western students in the Republic of Korea. FIRE, 6, 167-188. https://doi.org/10.32865/fire202062195

Teranishi, R. T., Ceja, M., Antonio, A. L., Allen, W. R., \& McDonough, P. M. (2004). The college-choice process for Asian Pacific Americans: Ethnicity and 
socioeconomic class in context. The Review of Higher Education, 27, 527-551. http://doi.org/10.1353/rhe.2004.0025

van de Werfhorst, H. G., \& Heath, A. (2019). Selectivity of migration and the educational disadvantages of second-generation immigrants in ten host societies. European Journal of Population, 35, 347-378. https://doi.org/10.1007/s10680-018-9484-2

Vrontis, D., Thrassou, A., \& Melanthiou, Y. (2007). A contemporary higher education student-choice model for developed countries. Journal of Business Research, 60, 979-989. https://doi.org/10.1016/j.jbusres.2007.01.023

Wilkins, S. (2016). Transnational higher education in the 21 st century. Journal of Studies in International Education [Editorial], 20, 3-7. https://doi.org/10.1177/1028315315625148

Wilkins, S., Balakrishnan, M. S., \& Huisman, J. (2012). Student choice in higher education: Motivations for choosing to study at an international branch campus. Journal of Studies in International Education, 16, 413-433. https://doi.org/10.1177/1028315311429002

Wilkins, S., \& Huisman, J. (2012). The international branch campus as transnational strategy in higher education. Higher Education, 64, 627-645. https://doi.org/10.1007/s 10734-012-9516-5

Wilkins, S., \& Epps, A. (2011). Student evaluation web sites as potential sources of consumer information in the United Arab Emirates. International Journal of Educational Management, 25, 410-422. https://doi.org/10.1108/09513541111146341

Wilkins, S., Shams, F., \& Huisman, J. (2013). The decision-making and changing behavioural dynamics of potential higher education students: The impacts of increasing tuition fees in England. Educational Studies, 39, 125-141. https://doi.org/10.1080/03055698.2012.681360

\begin{abstract}
About the Author
William H. Stewart, EdD, is currently the Inbound Exchange Student program manager at Hankuk University of Foreign Studies in Seoul, Korea. He completed a doctorate in Educational Technology (with a focus on distance education) from Boise State University. He has worked primarily in international and transnational education in both K-12 and higher education. His research interests are how distance education and transnational communities intersect, as well as student mobility and emerging trends in international education.
\end{abstract}

